\title{
MENGUAK FENOMENA KEMISKINAN DAN PEMAHAMAN KEAGAMAAN MASYARAKAT NELAYAN DI TELUK BUO
}

\author{
Masrial \\ UIN Imam Bonjol Padang \\ Email: masrialma@uinib.ac.id
}

\begin{abstract}
Abstrak
Secara ekonomi, nelayan dapat digolongkan sebagai penduduk yang memiliki pendapatan terendah, dan sering dikategorikan sebagai penduduk miskin. Kajian ini bertujuan untuk mengungkapkan dan menganalisis kehidupan sosial ekonomi masyarakat nelayan, bentuk-bentuk kemiskinan masyarakat nelayan, faktor-faktor penyebab kimiskinan masyarakat nelayan dan mengetahui pemahaman keagamaan masyarakat nelayan Teluk Buo dan pengaruhnya terhadap pemahaman keagamaan. Penelitian ini menggunakan pendekatan kualitatif dengan teknik pengumpulan data wawancara, observasi dan dolumentasi. Hasil penelitian menunjukan bahwa faktor-faktor penyebab kemiskinan dikalangan masyarakt nelayan Teluk Buo adalah sikap fatalistis dan ketergantungan masyarakat nelayan terhadap bantuan pemerintah. Hasil penelitian juga menunjukkan bahwa masyarakat Teluk Buo memahami kimiskinan itu adalah pemberian dari Allah, yang perlu disukuri. Masyakat nelayan Teluk Buo menyatakan bahwa kemiskinan itu bukalah penderitaan tetapi adalah suatu nikmat yang harus disukuri.
\end{abstract}

Kata kunci: Kemiskinan, masyarakat, nelayan, ekonomi, dan keagamaan.

\section{PENDAHULUAN}

Provinsi Sumatera Barat merupakan salah satu wilayah di Indonesia yang memiliki laut yang sangat luas. Sebagai daerah yang memiliki laut luas, ekonomi penduduk, khususnya masyarakat nelayan di daerah pesisir tergantung pada hasil laut. Salah satu daerah yang menjadi sentral nelayan adalah Teluk Buo Kelurahan Teluk Kabung Tengah Kecamatan Teluk Buo Kota Padang. Sebagian besar mereka berprofesi sebagai nelayan yang diperoleh secara turun temurun dari nenek moyang mereka. Kehidupan dan usaha mereka sangat tergantung pada hasil laut. Secara geografis, masyarakat nelayan adalah masyarakat yang hidup, tumbuh, dan berkembang di kawasan pesisir, yakni suatu kawasan transisi antara wilayah darat dan laut (Kusnadi, 2002).
Masyarakat nelayan sering dinilai lebih terbelakang daripada masyarakat perkotaan dalam hal derap pembangunan. Secara ekonomi, nelayan dapat digolongkan sebagai penduduk yang terendah tingkat pendapatannya atau dikategorikan golongan penduduk miskin. Perekonomian mereka sangat dipengaruhi oleh musim penangkapan ikan, kondisi alam, terbatasnya modal, alat penangkapan ikan yang masih tradisional, transportasi kurang lancar, kelembagaan ekonomi tidak mendukung, dan posisi nelayan dalam penentuan harga hasil tangkapan sangat lemah (Aulia Tellisa, 2009).

Berangkat dari fenomena ini, untuk dapat memberdayakan masyarakat nelayan Teluk Buo, harus dikenali terlebih dahulu sumber-sumber penyebab terjadinya kemiskinan pada masyarakat Teluk Buo. Ditinjau dari sumber penyebab kemiskinan, dikenal 
kemiskinan kultural dan kemiskinan struktural. Kemiskinan kultural mengacu pada sikap seseorang atau masyarakat yang disebabkan oleh gaya hidup, kebiasaan hidup dan budayanya. Kemiskinan struktural adalah kemiskinan yang disebabkan oleh karena struktur masyarakat yang tidak seimbang, baik dalam pemilikan/pengelolaan sumber daya, ketidakmerataan kesempatan berusaha, ketidaksamaan informasi atau akses sumberdaya, ataupun karena adanya kebijakkan pemerintah yang tidak berpihak padanya (Bambang Rudito dan Adi Prasetijo, 2003).

Kemiskinan disebabkan oleh banyak faktor, tidak banyak kemiskinan yang hanya disebabkan oleh faktor tunggal. Seseorang atau keluarga miskin bisa disebabkan oleh empat faktor yang saling terkait satu sama lain, yaitu; Pertama, Faktor individual, terkait dengan aspek patologis, termasuk kondisi fisik dan psikologis si miskin. Orang miskin disebabkan oleh perilaku, pilihan, atau kemampuan dari simiskin itu sendiri dalam menghadapi kehidupannya; Kedua, Faktor sosial, kondisi-kondisi lingkungan sosial yang menyebabkan seseorang menjadi miskin; Ketiga, Faktor kultural, kondisi atau kualitas budaya yang menyebabkan kemiskinan. Faktor ini secara khusus sering menunjuk pada konsep "kemiskinan kultural" atau "budaya kemiskinan" yang menghubungkan kemiskinan dengan kebiasaan hidup. Sikap-sikap "negatif" seperti malas, fatalisme atau menyerah pada nasib, tidak memiliki wirausaha, dan kurang menhormati etos kerja, misalnya, sering ditemukan pada orang-orang miskin; Kelima, Faktor struktural, Menunjuk pada struktur atau sistem yang tidak adil, tiadak sensitif dan tidak accessible sehingga menyebabkan seseorang atau sekelompok orang menjadi miskin. Sebagai contoh, sistem ekonomi neoliberalisme yang diterapkan di Indonesia telah menyebabkan para petani, nelayan, dan pekerja sektor informal terjerat dan sulit keluar dari kemiskinan. Sebaliknya, stimulasi ekonomi, pajak dan iklim investasi lebih menguntungkan orang kaya dan pemodal asing untuk terus menumpuk kekayaan (Bambang Rudito).

Sedangkan menurut Kartasasmita, ada empat penyebab kemiskinan yakni: Pertama, Rendahnya taraf pendidikan, taraf pendidikan yang rendah mengakibatkan kemampuan pengembangan diri terbatas dan menyebabkan sempitnya lapangan kerja yang dapat dimasuki; Kedua, Rendahnya derajat kesehatan, taraf kesehatan dan gizi yang rendah menyebabkan rendahnya daya tahan fisik, daya fikir dan prakarsa; Keempat, Terbatasnya lapangan kerja, lapangan kerja untuk rumah tangga miskin relatif terbatas; Kelima, Kondisi keterisolasian, banyak penduduk miskin secara ekonomi tidak berdaya karena terpencil dan terisolasi (Bambang Rudito).

Kebudayaan yang melekat pada masyarakat merupakan hal yang tidak bisa di hindari sebagai bentuk masalah sosial. Menurut Oscar Lewis dalam bukunya, Five Families: Mexican Case Studies in the Culture of Poverty, secara cemerlang menguraikan betapa orientasi nilai, pola hidup, dan cara berpikir orang miskin mencerminkan suatu kebudayaan kemiskinan. Tesis utamanya: orang miskin memiliki karakteristik dan nilai-nilai budaya yang berbeda dengan orang kebanyakan, yang kemudian membentuk sub-kultur 
tersendiri. Lewis menulis, "the culture of poverty indicates that poor people share deviant cultural characteristics; they have lifestyles that differ from the rest of society and these characteristics perpetuate their life of poverty." Jadi, kemiskinan bukan semata bersumber pada kebijakan negara yang didominasi golongan elite, yang melahirkan ketimpangan ekonomi. Atau regulasi pemerintah yang tak adil, sehingga membuahkan marginalisasi sosial.

Kondisi masyarakat Teluk Buo lebih memprihatinkan karena masyarakat Teluk Buo berada pada lingkungan kondisi kekayaan alam yang melimpah dan pendapatan yang cukup, namun masyarakatnya tidak berdaya. Masyarakat nelayan Teluk Buo belum mampu meningkatkan taraf perekonomiaan mereka ke arah yang lebih baik. Fenomena di atas sangat menarik di teliti lebih lanjut terutama terkait dengan faktor-faktor apa saja yang menyebabkan kemiskinan pada masyarakat nelayan Teluk Buo serta relevansinya terhadap pemahaman keagamaan.

Kajian ini bertujuan untuk menjelaskan dan mengungkapkan fenomena kemiskinan masyarakat nelayan. Mengungkapkan dan menganalisis kondisi objektif kehidupan sosial ekonomi masyarakat nelayan Teluk Buo; Menganalisis dan mengetahui bentuk-bentuk kemiskinan masyarakat nelayan Teluk Buo; Menganalisis dan mengetahui faktor penyebab kemiskinan masyasrakat nelayan Teluk Buo, dan menganalisis dan mengetahui pemahaman keagamaan masyarakat nelayan dan pengaruhnya terhadap budaya kerja masyarakat dalam peningkatan ekonomi.

\section{METODE PENELITIAN}

Penelitian ini berbentuk studi kasus kemasyarakatan yang berkaitan dengan masalah kemiskinan para nelayan. Penelitian ini menggunakan pendekatan kualitatif melalui grounded research, yang memungkinkan peneliti lansung mencari dan mengumpulkan data atas masalah yang dipelajari tanpa harus terikat untuk membuktikan benar atau tidaknya teori yang ada.

Subjek penelitian adalah semua masyarakat yang profesinya sebagai nelayan dengan tehnik pemilihan subjek dengan purporsive sampling. Penggunaan tehnik purporsive sampling dilakukan secara sengaja berdasarkan pertimbangan dengan cirri-ciri tertentu yang didapat memberikan keterwakilan informasi dari sejumlah subjek yang diteliti. Sedangkan sumber data dalam penelitian ini adalah masyarakat nelayan, pengurus RT dan RW, unsus pemerintahan kelurahan Teluk Kabung Tengah, tokoh adat, tokoh agama, dan dokumentasi.

Teknik pengumpulan data yang diugunakan dalam penelitian ini adalah observasi dan wawancara. Sedangkan teknik analisis data dilakukan mulai dari mereduksi data, setelah data direduksi, maka langkah selanjutnya adalah mendisplay data, penafsiran dan menarik kesimpulan.

\section{HASIL PENELITIAN DAN PEMBAHASAN}

\section{Gambaran Umum Lokasi Penelitian}

Teluk Buo sebagai salah satu nagari di Teluk Buo dikenal sebagai salah satu daerah wisata di kota Padang dengan panorama pantai yang indah. Dengan potensi alam yang dimiliki, sebagian besar penduduk berprofesi sebagai 
nelayan dan pengelola pantai (Haluan, 2015).

Tabel 1: Sebaran Penduduk Kelurahan Bungus Taluak Sirih

Berdasarkan Jenis Pekerjaan.

\begin{tabular}{llcc}
\hline No. & $\begin{array}{c}\text { Jenis } \\
\text { Pekerjaan }\end{array}$ & $\begin{array}{c}\text { Jumlah } \\
\text { (Jiwa) }\end{array}$ & $\begin{array}{c}\text { Persentase } \\
(\mathbf{\%})\end{array}$ \\
\hline 1. & Nelayan & 1456 & 48,2 \\
2. & Pegawai Negri & 479 & 15,8 \\
3. & Pedagang & 250 & 8,3 \\
4. & Swasta & 675 & 22,3 \\
5. & Pertukangan & 60 & 1,9 \\
6. & Pensiunan & 56 & 1,8 \\
7. & Peternakan & 50 & 1,6 \\
\hline & Jumlah & $\mathbf{3 0 2 6}$ & $\mathbf{1 0 0}$ \\
\hline
\end{tabular}

Sumber : Kantor Kelurahan Bungus Taluak Sirih 2014

Tabel 2 : Sebaran Penduduk menurut Jenis Kelamin dan Tingkatan Umur

\begin{tabular}{cccccc}
\hline No. & $\begin{array}{c}\text { Tingkatan } \\
\text { Umur }\end{array}$ & Jiwa & $\%$ & Jiwa & $\%$ \\
\hline 1. & $0-5$ & 242 & 5,6 & 328 & 7,2 \\
2. & $5-6$ & 158 & 3,6 & 167 & 3,7 \\
3. & $7-12$ & 204 & 4,7 & 215 & 4,7 \\
4. & $13-15$ & 264 & 10,7 & 451 & 10,0 \\
5. & $16-18$ & 423 & 9,8 & 432 & 9,5 \\
6. & $19-25$ & 471 & 10,9 & 470 & 10,4 \\
7. & $26-49$ & 722 & 16,7 & 746 & 16,4 \\
8. & $50-59$ & 756 & 17,4 & 817 & 17,9 \\
9. & $60-69$ & 701 & 16,3 & 731 & 16,1 \\
10. & 70 & 180 & 4,2 & 186 & 4,1 \\
\hline
\end{tabular}

Sumber : Kantor Kelurahan Bungus Taluak Sirih 2014

Masyarakat nelayan Teluk Buo umumnya berasal dari penduduk lokal dan sebagian kecil berasal dari luar daerah seperti: Pesisir, Pariaman, Deli Serdang bahkan dari Pulau Jawa. Bagi para nelayan yang berasal dari luar daerah mereka lebih memilih tinggal di dalam kapal yang mereka labuhkan di pinggiran pesisir pantai untuk mengurangi biaya kehidupan seharihari. Profesi nelayan sudah lama mereka lakukan dan sudah sangat berpengalaman yakni sekitar sepuluh sampai tiga puluh tahun bahkan ada yang mencapai empat puluh lima tahun berprofesi sebagai nelayan.

Setiap orang menginginkan pendidikan yang lebih baik, karena dengan pendidikan membantu seseorang menuju kesehjeteraan sosial, baik rohani maupun jasmani. Akan tetapi tidak semua orang mampu memenuhi persyaratan prosedur pendidikan secara ekonomi maupun kemauan mengikuti pendidikan itu sendiri.

Senada dengan uraian di atas Kartaharja (dalam Henny Gusril , 2015: 45) menyatakan tinggi rendahnya tingkat kesejahteraan seseorang atau sekelompok orang di perhitungkan dari komponen-komponen kesehatan, pakaian, pendidikan, perumahan dan pendapatan juga mencerminkan tingkat kesejahteraan. Dalam tabel di bawah ini dapat dilihat tingkat pendidikan masyarakat Teluk Buo.

Tabel 3: Sebaran Reponden Berdasarkan Tingkat Pendidikan

\begin{tabular}{lccc}
\hline No. & $\begin{array}{c}\text { Tingkat } \\
\text { Pendidikan }\end{array}$ & $\begin{array}{c}\text { Jumlah } \\
\text { (Orang) }\end{array}$ & $\begin{array}{c}\text { Persenta } \\
\text { se (\%) }\end{array}$ \\
\hline 1. & $<$ SD & 6 & 13,33 \\
2. & SD & 19 & 42,23 \\
3. & SLTP & 10 & 22,22 \\
4. & SLTA & 10 & 22,22 \\
\hline Jumlah & & $\mathbf{4 5}$ & $\mathbf{1 0 0 , 0 0}$ \\
\hline
\end{tabular}

Sumber : Kantor Keluraharan Bungus Taluak Sirih

\section{Jenis Alat Tangkap dan Perkembangan teknologi}

Jenis alat tangkap yang digunakan oleh para nelayan di Teluk Buo mengalami perubahan seiring perkembangan zaman. Tahun 1960-an para nelayan di Teluk Buo menggunakan dayung dan layar dalam kegiatan melaut atau menangkap ikan. Perahunya disebut dengan biduk yang ukurannya 
kecil dan tanpa menggunakan mesin. Tahun 1980-an masyarakat nelayan Teluk Buo sudah mulai menggunakan mesin (inboard motor), seperti Dong Feng yang berbahan bakar minyak solar. Mesin ini tidak lagi diletakkan dibagian samping perahu, melainkan didalam. Pada tahun 1990-an kecanggihan mesin semangkin meningkat, para nelayan sudah memakai mesin berkekuatan 7 PK. Tahun 2000-an, kapal-kapal besar sudah menggunakan mesin berkekuatan besar seperti tabel di bawah ini:

Tabel 4 : Jenis Alat Tangkap Perikan

\begin{tabular}{clc}
\multicolumn{3}{c}{ yang ada di Bungus } \\
\hline No. & $\begin{array}{c}\text { Jenis Alat } \\
\text { Tangkap }\end{array}$ & Jumlah \\
\hline 1. & Pukat Mesin & 12 \\
2. & Pukat Manual & 5 \\
3. & Jaring & 150 \\
4. & Perangkap & 40 \\
6 & Rawai & 2 \\
7. & Bagan & 5 \\
8. & Payang & 8 \\
\hline
\end{tabular}

Sumber. Dinas Kelautan dan Perikanan Kota Padang 2014

Sedangkan jenis ikan yang dihasilkan beragam sesuai dengan alat tangkap yang digunakan, seperti: ikan tongkol, hiu, selar, garapuh, kembung dan sebagainya. Para nelayan yang menggunakan perahu kecil (biduk) ikan hasil tangkapan berupa ikan kecil. seperti : Suaso, Kase, Pinang-pinang, Sinangih, Bada, Baledang, Tete, dan sebagainya.

Penghasilan nelayan sangat tergantung pada alat tangkap yang digunakan. Ada beberapa jenis ikan yang sering didapatkan oleh nelayan sesuai dengan musim yang ada, yaitu: Pertama, Ikan Kase, muncul ke daerah pinggiran pantai setiap bulan, ketika ombak tenang, selama 1-2 minggu. Pada musim ini, penghasilan nelayan di Teluk
Buo cukup memuaskan. Nelayan dapat menghasilkan 1-3 baskom ikan kase setiap harinya selama 2 minggu. Dengan harga jual per ember 150 ribu rupiah; Kedua, Ikan Pinang-Pinang dan Baledang, ikan ini biasanya muncul setelah musim ikan Kase berlalu. Jumlah ikan ini tidak sebanyak ikan kase, tetapi, harga jualnya lebih tinggi dibandingkan ikan kase yaitu kurang lebih Rp, 10.000 /kg; Ketiga, Ikan Suaso, ikan ini tidak diketahui pasti kapan munculnya, namun para nelayan akan melihat gerombolan ikan ini ketika muncul di permukaan pada musim terang. Karena keberadaan ikan ini jarang muncul, menjadikan ikan ini memeliki harga jual yang tinggi dan dijual oleh nelayan perekor saja.

Sehubungan dengna itu, nelayan tidak memilih jenis ikan, melainkan menangkap seluruh ikan yang masuk ke dalam pukat. Biasanya 9-10 keranjang berbagai jenis ikan yang kami bawa ke TPI. Dengan penghasilan itu, kami biasanya mendapat bagian sebesar 2-3 ratus ribu per orang. Sesuai dengan hasil penelitian Linda Waty Zen (2009: 16) tentang Anilis Kontribusi Pendapatan Wanita Nelayan di Kelurahan Bungus Taluak Sirih. Secara umum, penghasilan keluarga nelayan adalah sebagai berikut:

Tabel 5: Pendapatan Keluarga nelayan di Kelurahan Pasir Nan Tigo

\begin{tabular}{llrc}
\hline No. Indikator & $\begin{array}{c}\text { Terting- } \\
\text { gi (Rp.) }\end{array}$ & $\begin{array}{c}\text { Teren- } \\
\text { dah } \\
\text { (Rp.) }\end{array}$ & $\begin{array}{c}\text { Rata- } \\
\text { Rata } \\
\text { (Rp.) }\end{array}$ \\
\hline 1. $\begin{array}{l}\text { Pendapatan } \\
\text { suami/bula } \\
\mathrm{n}\end{array}$ & 2.200 .000 & 450.000 & 922.889 \\
2. Pendapatan & 1.100 .000 & 200.000 & 539.778 \\
$\begin{array}{l}\text { isteri/bln } \\
\text { 3. } \begin{array}{l}\text { Pendapatan } \\
\text { keluarga/bln }\end{array}\end{array}$ & 2.900 .000 & 800.000 & 1.462 .667 \\
4. $\begin{array}{l}\text { Kontribusi } \\
\text { pendapatan } \\
\text { wanita }\end{array}$ & $64,00 \%$ & $13,04 \%$ & $37,62 \%$ \\
\hline
\end{tabular}

Sumber : Linda Waty Zen, Analisis Kontribusi 


\section{Hubungan Sosial Masyarakat Nelayan}

Hubungan sosial adalah hubungan-hubungan sosial yang dinamis yang menyangkut hubungan antara individu, antar kelompokkelompok manusia, maupun individu dengan kelompok manusia lainnya sebagai akibat dari hasil interaksi antar sesama mereka (Soerjono Soekanto, 2004 :61).

Setiap lapisan masyarakat memiliki kebutuhan interaksi antara satu dengan lain, sebab manusia tidak dapat hidup tanpa adanya bantuan dari orang lain. Naluri tersebut menjadikan manusia senantiasa menjalin hubungan dengan lingkungan sosial dimana mereka berada. Proses sosial dalam hubungan tersebut di masyarakat akan membentuk stratifikasi kelas atas dan kelas bawah, dimana masing-masing dominan berinteraksi sesuai dengan kelasnya (Kusmanto, 1993: 105). Masyarakat nelayan adalah kelompok yang paling terpinggirkan diantara masyarakat lainnya. Mereka hidup berbaur dengan segala kebudayaan-kebudayaan yang mereka miliki.

Hubungan masyarakat nelayan di Teluk Buo dengan sesama sudah terjalin dengan baik. Tolong-menolong adalah tradisi masyarakat nelayan, hal ini terlihat saat mereka memperbaiki alat tangkap, mendorong perahu ke laut dan mendaratkan kembali, semuanya mereka lakukan secara bersama-sama. Eratnya hubungan diantara mereka dapat dilihat secara kasat mata ketika mereka pergi dan pulang melaut.

Adanya rasa kebersamaan tersebut diasumsikan sebagai bentuk strata atau kondisi sosial yang sama. Dengan kata lain, rasa kebersamaan yang timbul pada komunitas mereka dikarenakan adanya rasa senasib sepekerjaan yang mereka hadapi. Sebagaimana yang dijelaskan Elly M. Setiadi (2011: 102) rasa kebersamaan serta tolong menolong ditimbulkan oleh naluri karena menpunyai tujuan yang sama, kepentingan yang sama, nasib yang sama, idiologi yang sama dan sebagainya. Pada akhirnya terbentuk menjadi suatu kelompok sosial.

Kondisi masyarakat nelayan Teluk Buo sangat akrab dengan ombak- ombak besar yang menimbulkan kebisingan dan segala jenis angin yang tidak pernah menciptakan keheningan. Dengan kondisi tersebut, secara alamiyah menciptakan kebudayaan-kebudayaan pada masyarakat nelayan. Sehingga lingkungan membentuk kepribadian mereka yang kasar, berbicara yang keras, kemudian di dukung dengan penghasilan mereka tergantung cuaca (daily increments) sehingga mereka selalu berada dalam kecemasan.

Masyarakat nelayan Teluk Buo dalam berinteraksi dengan keluarga sering menggunakan kata-kata kotor dan sering berperilaku kasar terhadap anak dan istrinya ataupun sebaliknya. Ketika anaka/istrinya melakukan kesalahan baik sengaja ataupun tidak, kata-kata itu langsung keluar tanpa segan-segan (segala macam carut-marut). Kondisi ini berkaitan dengan penjelasan Darsono (1992:23) tentang lingkungan mempengaruhi kehidupan masyarakat yang berada di sekitarnya. Kenyataan ini, menggambarkan hubungan sosial nelayan dengan lingkungan sekitar, sangat besar dalam membentuk kepribadian masayarakat pantai, hingga akhirnya terihimbas ke keluarga, kemasyarakat dan sebagainya. 
Stuktur Kelas Masyarakat Nelayan

Kelas sosial merupakan sekelompok orang yang berada pada posisi yang sama dalam hubungannya dengan penguasaan alat produksi, yakni kelas pemilik dan kelas bukan pemilik (buruh). Dalam menentukan kelas sosial ada kriteria yang akan menjadi tumpuan utama yaitu, berdasarkan kepemilikan (property), berdasarkan otoritas (authority), dan berdasarkan keahlian (expertise). Jadi, buruh nelayan juga bisa menjadi kelas yang tertinggi ketika buruh tersebut mempunyai salah satu kriteria yang disebutkan diatas.

\section{Dengan}

mengombinasikan kategori kelas dari Marx (dalam Rilus, 2014: 14) the determinant of social classes was effective private property in the means of production dan kemudian dibandingkan dengan kondisi rill dilapangan, maka masyarakat nelayan Teluk Buo dapat dikelompokan menjadi: Kelas Pemodal/Tauke/Toke (merchant class); Kelas Pemilik (capital class); dan Kelas Buruh (Proletariat).

Kelas Pemodal/ Tauke (Merchant class), pada masyarakat nelayan Teluk Buo dinamakan dengan tauke. Adapun tingkatan merchant class tersebut, adalah: Pertama, Upper-upper class, kelas ini adalah pemodal yang terbesar dan terkaya dalam bisnis pembeli dan pengolah ikan di kalangan masyarakat nelayan Bungus dan mempunyai relasi paling luas dalam pemasaran; Kedua, Upper midle class, pada kelas ini penampung ikan kedua terbesar dikalangan masyarakat nelayan. Sudah pasti, keuntungan dan relasi yang dimikinya tidak sebesar upper-upper class; dan Ketiga, upper lower class, adalah kelas terendah pada golongan pemodal lainnya. Pembelian dan pemasaran yang dilakukan hanya sebatas tingkat lokal saja.
Kelas Pemilik (capital class), memiliki beberapa arti, pertama, (capital class) pemilik yang mempekerjakan buruh; kedua, (petty bougoise) pemilik yang bekerja sebagai buruh. Adapun Struktur kelas pemilik pada nelayan Teluk Buo adalah: Pertama, Capital Upper Class (Nelayan Besar), sering disebut nelayan besar atau kapitalis, yaitu pemilik modal dan keuntungan terbesar dalam kegiatan melaut. Biasanya, Upper Class ini mempunyai kapal-kapal besar atau sering disebut dengan Bagan khususnya di daerah Kota Padang, yang memiliki buruh kapal minimal sepuluh orang kru yang akan mengelola kapal tersebut. Dilihat dari segi teknologi alat tangkap yang mereka gunakan mebutuhkan dana yang cukup besar. Memiliki sarana yang cukup tinggi seperti, menggunakan lampu merkuri 400-500 watt yang jumlahnya berkisar 40-70 buah memakan modal sekitar 40 juta rupiah.

Selain itu, diperlukan juga sebuah perahu sederhana untuk pulang pergi ke bagan menjemput dan mengantar ikan dan logistik. Jadi, untuk membuat satu bagan dibutuhkan modal 500 juta rupiah. Namun, dibalik modal yang besar untuk memulai suatu usaha, maka keuntungan yang diperoleh juga besar.

\section{Capital Midle Class (Nelayan} Menengah, juga termasuk kelas nelayan kapitalis menengah (capital midle class). Secara umum, nelayan Teluk Buo menggunakan pukat manual, mempunyai buruh minimal 8 orang dewasa yang mampu menarik pukat mersama-sama. Nelayan menengah ini umumnya memakai mesin Yamaha Enduro yang berkekuatan 40 PK. Penghasilan biasanya mencapai 6-10 keranjang perhari, jumlah yang cukup banyak untuk nelayan menengah. Akan tetapi ketika musim panceklik tiba, pendapatan mereka lebih kecil dari 
nelayan biasa.

Selain menggunakan pemukat manual, nelayan penjaring ada juga yang masuk kategori nelayan menengah (middle class). Namun, kualitas mesin, alat tangkap dan ukuran sampan juga sama dengan pemukat manual. Sementara itu untuk biaya operasi penangkapan dengan menggunakan Payang dalam sehari mencapai seratus limah puluh sampai dua ratus limah puluh ribu perhari.

Capital Lower Class (Nelayan Kecil), termasuk (property bourgoise) biasanya menggunakan perahu kecil yang berukuran panjang 7 meter dan lebar 80$90 \mathrm{~cm}$, menggunakan mesin bermerek Honda yang di dapatkan dari bantuan pemerintah dan sebagian dari partai politik yang mencalon menjadi anggota legislatif. Tidak semua lower class bersifat property bourgoise, karena ada sebahagian nelayan lower class yang mempekerjakan buruh walau 1-2 buruh saja.

Buruh Nelayan (proletariat), sering disebut ABK (Anak Buah Kapal). Sedangkan di Teluk Buo tetap di panggil dengan sebutan buruh. Isu kelas pada kaum nelayan berkaitan erat dengan alat tangkap yang digunakan. Di Teluk Buo kelas buruh tidak terdapat pada semua jenis alat tangkap. Ada alat tertentu yang tidak bisa digunakan seorang nelayan saja tanpa menggunakan bantuan buruh, seperti alat tangkap pukat manual. Alat tangkap ini minimal menggunakan 6 orang dewasa, agar mampu menarik pukat dengan cepat dan menagkap ikan yang cukup banyak. Adapun kelas buruh yang ada di Teluk Buo, adalah: Pertama, Buruh (upper class), adalah strata yang tertinggi dalam tingkatan kelas buruh, karena dilihat dari segi teknologi yang mereka gunakan pada saat melakukan operasional penangkapan ikan. Bagan dan Tundo adalah perahu yang memiliki alat teknologi penangkapan yang tertinggi di Bungus; Kedua, Buruh (midle class), adalah kelas menengah dalam strata kelas buruh di Bungus. Karena alat tegnologi yang mereka gunakan adalah Payang, yang menggunakan pukat manual dalam melakukan operasi penangkapan ikan. Ketiga, Buruh (lower class), strata terakhir dan terendah adalah buruh lower class yang bekerja dengan capital lower class yang menggunakan alat sederhana dalam melakukan operasional penangkapan ikan.

\section{Faktor Penyebab Kemiskinan Nelayan}

Munculnya kemiskinan berkaitan dengan budaya yang hidup dalam masyarakat, ketidakadilan dalam pemilikan faktor produksi dan penggunaan model pendekatan pembangunan yang dianut oleh suatu negara, Soetrisno (1995: 2-3). Kondisi kemiskinan yang dialami oleh suatu masyarakat dalam jangka panjang, pada umumnya telah mempengaruhi berbagai prilaku dan gaya hidup masyarakat. Beberapa diantaranya adalah sikap fatalistis dan ketergantungan. Sikap fatalistis merupakan kondisi yang kurang mendukung adanya upaya dan motivasi untuk meningkatkan kondisi kehidupannya yang sebetulnya sangat diperlukan bagi pengentasan kemiskinan. Seperti yang yang terjadi dalam masyarakat nelayan Teluk Buo, ada beberapa faktor yang menyebabkan mereka tetap berada digaris kemiskinan, antara lain sebagai berikut: Tingginya sikap fatalistis, ingroup orientation dan ketergantungan masyarakat nelayan Teluk Buo kepada pemerintah.

Sikap fatalistis adalah kurangnya 
motivasi dalam meningkatkatkan kondisi kehidupannya. Karena yang terpenting agar seseorang atau sekolompok masyarakat keluar dari garis kemiskinan adalah timbulnya motivasi untuk maju dari dalam diri masyarakat itu sendiri. Apabila upaya keluar dari kondisi kemiskinan telah muncul dari dalam diri masyarakat itu sendiri, maka yang dibutuhkan adalah adanya achievement motivation yang tinggi dan itu sangat sulit diharapkan dari masyarakat yang memiliki sikap fatalistis. Maka yang terjadi pada masyarakat tersebut, tetap berada dalam lingkaran kemiskinan (Soetomo, 2010: 284 ).

Sehubungan dengan itu, masyarakat nelayan Teluk Buo, sikap fatalistik ini sangat banyak ditemukan. Motivasi yang dimiliki masyarakat nelayan sangat minim, hingga berpuluhpuluh tahun mereka bekerja sebagai nelayan tetap sulit merubah tarap kehidupannya. Kebanyakan dari ibu rumah tangga nelayan yang ada hanya menunggu hasil dari suami yang pulang melaut. Walaupun ada ibu rumah tangga yang membantu perekonomian keluarga, itu hanya sebatas mengisi waktu luang saja, seperti menjual kerupuk dengan penghasilan 10 ribu hingga 15 ribu untuk menambah uang belanja anak sekolah.

Uraian di atas, menyiratkan bahwa sikap fatalistis masih tinggi pada ibu rumah tangga nelayan, yaitu kurangnya motivasi kerja, tidak mempunyai keinginan prestasi untuk pengembangan usaha yang dimilikinya. Pernyataan tersebut tidak sesuai dengan yang dinyatakan oleh Sukardi (dalam Rambat Lupiyoadi, 2004: 6) untuk meningkatkan usaha yang dimiliki harus mempunyai sifat prestatif dan mampu melihat peluang yang ada. Walaupun masyarakat nelayan Teluk Buo melakukan suatu usaha, tetapi masih memiliki sikap fatalistis, mereka tetap berada dalam garis kemiskinan.

Sikap yang kurang menguntungkan masyarakat nelayan Teluk Buo adalah ingroup orientation. Sikap ini cendrung melihat kondisi dan nilai-nilai internal sebagai ukuran, sehingga masyarakat kurang responsive terhadap pembaharuan-pembaharuan. Sementara itu, ketergantungan mengakibatkan masyarakat kurang mampu bergerak atas inisiatif dan kekuatan sendiri, masyarakat bergerak melakukan suatu usaha apabila didorong dan didukung kekuatan dari luar. Sudah jelas kondisi ini sangat tidak mendukung tumbuhnya kemampuan masyarakat untuk mengembangkan proses dan usaha peningkatan taraf hidup yang berstandarkan kesehjeteraan sosial.

Kemiskinan dapat muncul akibat sistem politik, idiologi/agama dan sosial budaya yang berkembang (Tamrin Kamal, 2015). Hal ini berkaitan dengan pemahaman tauhid yang bersifat jabariyah. Pemahaman teologi yang mengakui bahwa semua keadaan dan perbuatan manusia telah ditentukan Allah, sehingga manusia hanya menerima dengan pasrah. Keyakinan seperti ini, jelas akan memperburuk kemiskanan atau menimbulkan kemiskinan baru. Penganut teologi ini berkeyakinan, bahwa tekanan ekonomi atau kemiskinan yang mereka derita, merupakan taqdir dari Allah yang harus diterima dengan kesabaran. Padahal kemiskinan menunjukkan rusakanya tatanan kehidupan yang harus diperbaiki.

Sikap ketergantungan juga melekat erat pada masyarakat nelayan Teluk Buo. Pola fikir yang mereka miliki bersifat instan, lebih memilih materil 
daripada pendidikan. Sehingga yang terjadi, tidak ada perubahan memperbaiki diri untuk masa mendatang. Namun, jika ada pembagian uang untuk anak usia sekolah maka orang tua mendorong anaknya ke sekolah (Rumah Anak Sholeh), tetapi ketika disusuruh belajar orang tua cuek dan acuh tak acuh.

Pola fikir mereka yang berjangka pendek, memilih kenikmatan semu daripada yang sesungguhnya. Ini sesuai dengan yang dinyatakan Soetomo (2010: 285), masyarakat cendrung menjadi miskin, karena memiliki unsur-unsur budaya yang kurang kondusif bagi penciptaan kondisi kehidupan yang lebih baik. Etos kerja yang kurang mendukung, semangat berusaha serta kerja keras yaang rendah, tingkah laku dan gaya hidup yang digambarkan sebagai aktualisasi budaya kemiskinan. Hal ini merupakan hasil penyesuaian atau adaptasi masyarakat terhadap kondisi kemiskinan yang cukup lama melilitnya.

Rendahnya
masyarakat nelayan Teluk Buo,
kemiskinan yang terjadi pada
masyarakat umumnya diakibatkan
pendidikan yang rendah. Kekayaan
alam tidak menjamin masyarakat
setempat hidup makmur dan
berkecukupan, melainkan kemampuan
masyarakat dalam mengelola potensi
lokal yang ada.

Potensi lokal yang ada di Teluk Buo, bukan salah satu penyebab kemiskinan pada masyarakat nelayan. Karena Teluk Buo memiliki potensi alam yang yang cukup tinggi, baik itu dari segi wisata alam maupun hasil produksi ikan yang dimiliki. Namun, karena keterbatasan dan pengetahuan mereka yang rendah menyebabkan mereka tidak mampu mengolah dan memenej potensi lokal yang ada. Hingga akhirnya, marsyarakat nelayan Teluk Buo tetap dililit kemiskinan. Walaupun, banyak program-program pemerintah dan Lembaga Swadaya Msyarakat (LSM) meluncurkan program pemberdayaan masyarakat, untuk membantu mengelolah dan membina potensi lokal yang ada.

Sistem penjualan hasil produksi nelayan yang tidak kondusif dan terlalu murah, lebih menguntungkan agen-agen ikan. Hal ini disebabkan proses jual beli antara nelayan dengan Tempat Pelelangan Ikan (TPI) sangat tidak kondusif. Nelayan menjual ikan di TPI dengan takaran per ember atau keranjang dengan harga yang relatif murah, sedangkan TPI memasarkan ikan tersebut berdasarkan satuan kilogram dengan harga yang cukup tinggi, bahkan mencapai dua kali lipat dari harga yang mereka beli kepada nelayan.

Selain itu, banyak pengunjung yang sengaja datang ke Teluk Buo untuk membeli ikan dengan harga murah karna langsung datang ke pinggiran pantai. Para nelayan hanya menjual hasil tangkap mereka dengan takaran onggokan kecuali ikan suaso yang dijual per ekor karena susah ditemukan. Kondisi ini sangat tidak menguntungkan masyarakat nelayan. Secara tidak langsung, para nelayan tereksploitasi oleh tindakan pembeli atau TPI yang membeli ikan dengan harga yang relatif murah dengan memanfaatkan keterbatasan kemampuan para nelayan menjual hasil produksinya.

Kondisi di atas diperburuk oleh sistem bagi hasil yang tidak seimbang antara buruh nelayan dengan induak samang (pemilik kapal). Sesuai dengan sistem bagi hasil, nelayan buruh dengan 
induak samang sangat menindas para buruh sehingga untung yang didapat oleh induk samang sangat besar. Sistem bagi hasil yang diterima para buruh setelah kembali dari laut tidak memadai, seperti buruh berjumlah 15 orang, penghasilan yang di capai sehari sebesar 2 juta rupiah. Kemudian pemilik modal memberi 100 ribu per buruh termasuk pemilik modal itu sendiri dari jumlah penghasilan yang 2 juta. Sedangkan sisanya sebesar 400 ribu disimpan dalam 25 hari, setelah sampai 25 hari maka bejumlah 10 juta rupiah, selanjutnya dibagi menjadi 2 bagian yaitu kepada pemilik kapal dan operasional seharisehari pergi melaut. Pembagian hasil yang demikian, menguntungkan pemilik kapal dan kaum buruh sangat tereksploitasi. Perbandingan pembagian antara pemilik modal dengan buruh 3 (pemilik kapal) : 1 (buruh) dengan bagian yang tidak merata.

Ketidak seimbangan alat tangkap nelayan modren, menengah dan tradisional di Teluk Buo. Perbedaan alat tangkap, menyebabkan adanya pihak yang dirugikan. Seperti halnya "Revolusi Hijau" atau modernisasi dibidang pertanian, kebijakan "Revolusi Biru" berupa program motorisasi perahu nelayan dan modernisasi alat tangkap sebetulnya telah lama menuai kecaman. Kebijakan modernisasi perikanan ini, terbukti mendorong timbulnya gejala lebih tangkap (over fishing) dan pengurasan sumberdaya perikanan secara eksploitatif di perairan pantai maupun di perairan lepas pantai. (Suhartini, 2005: 65).

Kendati harus diakui bahwa modernisasi di sektor perikanan secara kuantitas memang telah berhasil meningkatkan jumlah total tangkapan nelayan, tetapi disisi lain modernisasi perikanan sesungguhya menimbulkan masalah. Karena, pengadaan modernisasi alat tangkap kepada seluruh lapisan masyarakat nelayan, tidak semua mampu untuk membeli, apalagi harus memiliki alat tangkap yang begitu modern, hanya juraganjuragan kaya yang mampu membeli alat tangkap tersebut, sedangkan nelayan tradisional tidak sanggup untuk memilikinya. Jadi, dalam kondisi ini, nelayan tradisional yang menjadi korban "Revolusi Biru" dan tangkapan mereka semangkin berkurang, dikarenakan semangkin habisnya sumberdaya laut di pesisir pantai.

Keuntungan dipegang oleh nelayan besar, kecanggihan tegnologi yang mereka miliki mampu menguras sumberdaya laut begitu mudah, juraganjuragan kapal semangkin kaya dan terus menambah alat tangkap ya semangkin cangggih dan memperbanyak kapalkapal penangkapan ikan. Hingga akhirnya, jelas ini sangat menindas para nelayan kecil karena keterbatasan alat tangkap yang mereka miliki.

\section{Pemahaman Masyarakat tentang Kemiskinan}

Secara konseptual, pemahaman seseorang tentang kemiskinan adalah hal yang wajar sebagai fitrah Allah SWT. Namun, kemiskinan yang seperti ini dapat dirubah dengan usaha-usaha serta motivasi yang tinggi untuk maju dan prestatif. Berbagai kalangan telah banyak memaknai kemiskinan itu serta merealisasikan dalam kehidupan nyata.

\section{Sedangkan}

pemahaman masyarakat nelayan Bungus terhadap kemiskinan, mengungkapkan bahwa rezeki itu akan datang dari Tuhan tanpa ada kerja keras serta prestatif dengan melihat peluang yang lebih besar. Kemiskinan itu diartikan bukan sebagai penderitaan, akan tetapi kemiskinan itu 
adalah suatu nikmat yang harus disukuri karena terus mengingat Tuhan. Lebih jauh lagi, pemahaman di atas diartikan sebagai salah satu zuhud untuk mendekatkan diri pada Tuhan dan menjauhkan diri dari kesombongan. Konsep zuhud bukan berarti memilih hidup menjadi miskin. Zuhud itu bukan soal kaya atau miskin, tetapi tentang presepsi kita terhadap harta, yang dapat mengendalikan harta dan dunia. Meninggalkan dunia karena mengharapkan sesuatu yang lebih baik, bukan berarti kita harus miskin (Ibnu Qoyyim, 1998: 147). Kalau ditinjau dari pandangan Islam, tidak ada satupun yang memuji kemiskinan. Kemiskinan itu sangat berbahaya bagi akidah, berbahaya bagi akhlak dan prilaku, pikiran dan ketentram masyarakat. Makanya Islam menganjurkan kita untuk kaya.

Selanjutnya ketika mendapat rezeki, langsung dihabiskankan yang diibaratkan seperti harimau yang mendapatkan makanan. Menghabiskan penghasilan dengan waktu yang singkat mencerminkan pemahaman kemiskinan yang ditimbulkan oleh dirinya sendiri. Sedangkan yang tidak berani bertarung dengan kehidupan, dalam artian hanya mencari titik posisi aman, walaupun kehidupan yang dijalani dibawah kesehjateraan.

Kemiskinan yang terjadi pada diri mereka adalah suatu takdir yang tidak dapat di ubah. Melihat pandangan tersebut, ini seperti pandangan kelompok Fatalis yang mengatakan kemiskinan adalah sebagai takdir dan kudrat Tuhan. Semua keadaan dan perbuatan manusia sudah ditentukan Tuhan, sehingga manusia hanya bersifat menerima dengan pasrah (Tamrin Kamal, 2015 : 74)
Menurut Islam, bekerja adalah satu-satunya cara yang mutlak, untuk mendapatkan penghasilan. Setiap manusia diwajibkan berusaha merubah keadaannya, bukan hanya berdiam diri atas keadaan yang menimpahnya bahkan sampai meratapinya. Sebagaimana yang dijelaskan dalam Alqur'an surat An-nisa' ayat 32 :

"Dan janganlah kamu iri terhadap apa yang dikaruniakan Allah kepada sebahagian kamu lebih banyak dari sebahagian yang lain. Karena, bagi orang laki-laki ada bagian dari pada apa yang mereka usahakan, dan bagian para wanita (pun) ada bagian dari apa yang mereka usahakan"

Pandangan kemiskinan yang diceritakan di atas, seluruhnya mengenai tentang budaya kemiskinan (culture of poverty) adaptasi dan reaksi kaum miskin terhadap kedudukan marginal mereka dimana kebudayaan tersebut cendrung melanggengkan dirinya dari generasi ke generasi. Kebudayaan tersebut upaya mengatasi keputus asaan dari angan sukses di dalam kehidupan yang sesuai dengan nilai dan tujuan masyarakat yang lebih luas.

\section{PENUTUP}

Masyarakat nelayan Teluk Buo sebagian besar berasal dari penduduk lokal, namun ada juga sebagian berasal dari luar daerah. Seperti: Pesisir, Parianman, Deli Serdang bahkan dari Pulau Jawa. Bagi para nelayan yang berasal dari luar daerah mereka lebih memilih tinggal di dalam kapal yang mereka labuhkan di pinggiran pesisir pantai untuk mengurangi biaya kehidupan sehari-hari. Profesi nelayan sudah cukup lama mereka lakukan dan sudah sangat berpengalaman yakni 
sekitar sepuluh sampai tiga puluh tahun bahkan ada yang mencapai empat puluh lima tahun berprofesi sebagai nelayan. Mereka melaut setiap hari kecuali harihari tertentu seperti badai dan hal-hal yang menyebabkan mereka tidak bisa pergi melaut.

Struktur kelas yang terjadi pada masyarakat nelayan Teluk Buo sangat mengeksploitasi kaum buruh, yang tidak bisa berbuat apa-apa karena sangat membutuhkan pekerjaan. Kemiskinan yang dialami masyarakat nelayan Teluk Buo bukan hanya dikarenakan rendahnya penghasilan yang mereka dapatkan. Namun, didukung juga dengan kecendrungan sikap fatalistik, motivasi yang dimiliki masyarakat nelayan Teluk Buo sangat minim, ingroup orientation. Sikap ini cendrung melihat kondisi dan nilai-nilai internal sebagai ukuran, sehingga masyarakat kurang respon terhadap pembaharuanpembaharuan. Sementara itu, ketergantungan mengakibatkan masyarakat kurang mampu bergerak atas inisiatif dan kekuatan sendiri, masyarakat bergerak melakukan suatu usaha apabila didorong dan didukung kekuatan dari luar.

Selanjutnya, sikap ketergantungan juga melekat erat pada masyarakat nelayan Teluk Buo. Pola pikir yang mereka miliki bersifat instan, lebih memilih materil daripada pendidikan. Sehingga yang terjadi, tidak adanya keinginan untuk memperbaiki diri. Adapun penghasilan masyarakat nelayan Teluk Buo rata-rata mencapai 70-120 ribu rupiah perharinya.

\section{DAFTAR PUSTAKA}

Ahmad Hatta, Tafsir Qur'an Per Kata Dilengkapi dengan Asbabun Nuzul dan Terjemah,( Jakarta : Maghfirah Pustaka, 2011)

Aminah, Siti, Pemberdayaan Sosial PetaniNelayan, Keunikan Agroekosistem, dan Daya Saing,( Jakarta: Yayasan Pustaka Obor Indonesia, 2014).

Andre Bayo, Kemiskinan dan Strategi Memerangi Kemiskinan, (Yogya : Liberty, 1981)

Andi Prastowo, Metode Penelitian Kualitatif Dalam presfekti rancangan penelitian, (Jogjakarta Ar-Ruzz media, 2011)

Afrida, Kehidupan sosial-ekonomi masyarakat nelayan di pantai utara pulau jawa tengah, (Bandung : Jurnal Antropologi, 2005)

Basrowi. Pengantar Sosiologi, (Bogor: Ghalia Indonesia, 2005)

Baudrillard, Jean P. Masyarakat Konsumsi, Yogyakarta: Kreasi Wacana, 2004

Chabib Sholeh, 2014. Dialektikan Pembangunan dengan Pemberdayaan Masyarakat, Bandung : Fokus Media

Chambers, Robert, Rural Development, Putting the Last First,( Longman: London,1983)

Djajadiningrat, Surna dkk, 2003, Akses Peran Serta Masyarakat, Jakarta : 
Indonesia Center For Sustainable Development.

Elly M, Setiadi dan Usman Kholif, Pengantar Sosiologi Pemahaman Fakta dan Gejala Pemahaman Sosial, Teori, Aplikasi dan Pemecahannya,(Jakarta : Kencana, 2011)

Franz, Magnis Suseno, Pemikiran Karl Marx: Dari Sosialisme Utopis ke Perselisihan Revisionisme, (Gramedia Pustaka: Jakarta, 2010).

Henny Gusril, Hubungan antara Latar Belakang Nelayan dengan Tingkat Pendapatannya dikelurahan Bungus Taluak Sirih Kecamatan Koto Tangag Padang (Padang: Jurnal LPPM UMSB, 2015)

Kamal, Tamrin, Teologi Sosial Islam “ Mengimplikasikan

Nilai-Nilai Ketuhanan Dalam Kehidupan Sosial Umat", (Padang : Imam Bonjol Pres, 2015).

Ketut Sudhana Astika, Budaya Kemiskinan dimasyarakat : Tinjauan Kondisi Kemiskinan dan Kesaran Masyarakat Budaya Miskin di Masyarakat, ( Bali : Jurnal Sosiologi, 2010).

Kumanto, Sunarto, Pengantar Sosiologi (Jakarta: Fakultas Ekonomi Universitas Indonesia, 1993)

Kusnadi. 2000. Strategi Adaptasi Dan Jaringan Sosial. Bandung :HumanioraUtama Press.
Kusnadi, Akar Kemiskinan Nelayan, (Yogyakarta: LKIS, 2002).

Kusnadi, "Makalah ilmiah disampaikan dalam kegiatan Jelajah Budaya", Kebudayaan masyarakat nelayan, (Yogyakarta: Perpustakaan UGM, 2010).

Koentjoroningrat, Metode-Metode Penelitian Masyarakat, (Jakarta : PT Gramedia, 1993)

Linda Waty Zen, Analis Kontribusi Pendapatan Wanita Nelayan di Kelurahan Pasie Nantigo Kecamatan Koto Tangah Kota Padang, (Padang: Jurnal, 2009)

Muliono, Pengemis dan Disfungsi Sistem Sosial Kultural dalam Masyarakat Minang Kabau, (Padang : Imam Bonjol Pres, 2013)

Mudrad Kuncoro, Strategi dan Teknik untuk Pengentasan Kemiskinan di Indonesia (Jakarta : Kompas, 2003)

Michel, focault, Wacana Kuasa/ Pengetahuan, diterj, Yudi Santoso, (Yogyakarta : Bentang Budaya, 2003)

Moeljarto, (1995). Politik Pembanguan Sebuah Analisis Konsep, Arah dan Strategi, PT. Tiara Wacana : Yogyakarta

Mardimin, yohannes, Kritisi Proses 
Pembangunan di Indonesia, (Kanisius : Yogyakarta, 1996)

Narbuko, Cholid, Metode Penelitian, (Jakarta : Bumi Aksara, 2009)

Petrus Guntur, 2008, Kemiskinan dan Struktural Fungsional, Jakarta : Kencana

Rilus A, Kingseng, Konflik Nelayan,(Jakarta : Yayasan Pustaka Obor Indonesia, 2014)

Rambat Lupiyoadi, Entrepreneurship From mindsed to strategy, (Jakarta : Lembaga Penerbitan Fakultas Ekonomi Inddonesia, 2004)

Raho, Bernard, Teori Sosiologi Modern (Jakarta: PrestasiPustaka, 2007), h. 126.

Sudarwati, Ninik, 2009, Kebijakan Pengentasan Kemiskinan Mengurangi Kegagalan Penanggulangan Kemiskinan, Malang: Intimedia

Sujatmiko, Eko, Kamus Ilmu Pengetahuan Sosial,(Aksara Sinergi Media : Surakarta, 2014).

Sindung Hariyanto, Spektrum Teori Sosial Dari Klasik Hingga Postmodren (Jogjakarta : Ar-Ruzz Media, 2012)

Suatmiko, Studi Fenomenologi Prilaku Penumpang di atas Gerbong Kreta Api, ( Surabaya : Jurnal, 2014)
Soetrisno, LoekmanMenuju Masyarakat Partisipatif, (Kanisius Yogyakarta,1995

Soerjono Soekanto, Sosiologi Suatu Pengantar, (Jakarta: Raja Grafindo Persada,2010

Tellisa ,Aulia, Penanggulangan Kemiskinandi Perkotaan dan Kemiskinan Aspek Sosial Budaya, (Draf Laporan Final Hibah Multisiplin UI, 2009)

Zainuddin, Optimalisasi Pengentasan Kemiskinan : Studi Tentang Manajemen Pelaksanaan UU Zakat No 38 1999, (Jurnal, MD Vol. I No. 1, 2008) 